\title{
CHALLENGES OF USING THE BUS AS AN OLDER PERSON
}

\author{
ANDREW MORRIS, JO BARNES \& BRIAN FILDES \\ Loughborough University, London, UK
}

\begin{abstract}
The UK public transport system is generally considered to be safe. However, annually around 6,000 people are reported to be injured whilst using buses with more than 400 persons killed or seriously injured. Approximately $50 \%$ of those injured or killed are aged over 65 years. Free travel on buses has allowed senior citizens the freedom to travel for pleasure and social inclusion, but injuries or near-falls that may occur during the journey can impact on future decisions to travel leading to anxiety/fear of sustaining further injury, loss of personal mobility and ultimately social isolation. A study was undertaken to examine the general safety of older bus users. It explored injury type and causation and proposed design interventions for injury prevention with an objective of exploring how public transport use could possibly be made safer. Consultations were also undertaken with stakeholders which revealed the perceived need for better data systems. Industry stakeholders supported the concept of national injury surveillance databases that could enhance bus safety and inform policy and procedures. Older bus passengers enjoyed the freedom that "free" travel brought to their everyday lives and this social impact dominated discussions with them. However, many had witnessed near-falls and "stumbling" and some had experienced this type of event. However interestingly, many did not report these events to the drivers and accepted that it was an everyday occurrence. None of the interviewees normally asked drivers to wait for them to sit down after they had boarded the bus before the bus moved - but also complained that the drivers were not obliging in this regard. Further to this, observation studies revealed that many older passengers were standing up to alight for a considerable length of time prior to the bus stopping at their individual stops thereby significantly increasing their chances of falling.
\end{abstract}

Keywords: elderly, public transport, injury, older passengers.

\section{INTRODUCTION}

It is projected that there will be a rise of $31 \%$ in the number of people of state pension age in the UK from 12.3 million (mid-2012) to 16.1 million (mid-2037), taking into account future rises in the state pension age. Maintaining independence is vital to wellbeing which often means reliance on public transport once driving is no longer an option. This reliance requires these services to be "age friendly" encouraging participation in the community [1]. However, during the period 2008 to 2012, over 20,000 UK bus and coach users were injured whilst using this form of transport and older passengers were more likely to sustain injuries [2]. The aim of this paper is to present a summary of the findings from the final report "Improving safety for older public transport users (OPTU) - a feasibility study" [3], which explored the challenges of older bus passengers from the perspectives of the older passengers and stakeholders.

\section{METHODS}

A mixed methods approach was used to collect the data using focus groups, questionnaires and survey data with the intention of providing broad insights into the problem of injuries on public transport. 


\subsection{Focus groups}

Three focus groups were held with local residents in the target groups of $60+$ years and who were able to contribute as either users of public transport or non-users. All the recorded interviews were transcribed and analysed using NVivo 10 to enable thematic content analysis. One researcher carried out all the analysis and coded paragraphs and sentences under broad or specific themes and would refer back to the original transcription to ensure context was maintained. A second researcher independently coded to the main themes to ensure inter-rater reliability [4].

\subsection{Stakeholder and bus drive consultations}

Initial interviews were conducted with eight stakeholders and these were asked to forward an online questionnaire link to other relevant contacts in their organisation to complete. The aim of the stakeholder survey was to illicit their opinions about the safety and use of buses by older passengers.

For the bus drivers, an anonymous questionnaire survey was developed and approved by a bus company manager before distributing to bus drivers of a small bus company. The distribution occurred on payday and the drivers received a questionnaire with their payslip to encourage their completion.

\section{RESULTS}

A descriptive summary of the results for each of the methods are presented in table 1, with specific pertinent results presented separately below.

Table 1: Descriptive summary of responses.

\begin{tabular}{|c|c|c|}
\hline Method & Target group & Responses \\
\hline Focus Groups & $\begin{array}{l}\text { Older public transport } \\
\text { users }(60+\text { years) in the } \\
\text { local community }\end{array}$ & $\begin{array}{l}\text { Three focus groups were held over a } 3 \text { week period } \\
\text { with a total of } 15 \text { participants. Overall there were } 9 \\
\text { females }(60 \%) \text { and } 6 \text { males ( } 40 \% \text { ) with a mean age } \\
72 \text { years (range } 62-88 \text { years, SD } 76.69 \text { ) and males } \\
\text { tended to be younger than females ( } 69 \text { years and } 74 \\
\text { years). There were } 4 \text { non users (or very occasional } \\
\text { users) of public transport those that used transport } \\
\text { regularly travelled } 3.6 \text { days a week - median } 4 \text { days }\end{array}$ \\
\hline Stakeholder survey & $\begin{array}{l}\text { Targeted interviews with } \\
\text { key persons and follow } \\
\text { up online questionnaire } \\
\text { surveys within the } \\
\text { stakeholders contacts }\end{array}$ & $\begin{array}{l}\text { A total of } 18 \text { online questionnaires were completed } \\
\text { and analysed using descriptive statistics. There } \\
\text { responses were received from operators }(n=4) \text {, } \\
\text { manufacturers }(n=4) \text {, suppliers ( } n=1) \text {, user groups } \\
(n=3) \text { and members of the Passenger Transport } \\
\text { Executive Group }(n=6) \text {. All of these stakeholders } \\
\text { dealt with buses with some covering other transport } \\
\text { modes i.e. train, trams, minibuses and coaches. }\end{array}$ \\
\hline Bus driver - survey & $\begin{array}{l}\text { Anonymous } \\
\text { questionnaires }-(\mathrm{n}=50) \text {, } \\
\text { distributed at } 1 \text { bus } \\
\text { garage in the local area. }\end{array}$ & $\begin{array}{l}\text { A total of } 28 \text { completed questionnaires were } \\
\text { returned. The majority of drivers were males } \\
(\mathrm{n}=19,67 \%), 6 \text { were females }(21 \%) \text { and } 3 \text { not } \\
\text { stated }(11 \%) \text {. Most of the drivers were aged } \\
\text { between } 50 \text { and } 59 \text { years }(39 \% n=11) .\end{array}$ \\
\hline
\end{tabular}




\subsection{Focus groups}

This analysis produced key themes that emerged from the focus groups and described here "access to travel and interaction with the transport".

\subsubsection{Reasons for transport choices}

Overall older passengers considered their bus passes as a "social" pass allowing them to develop and maintain social contact with friends and acquaintances and also provided a change of scenery that was considered important to prevent social isolation that could lead to depression. The predominant reason for travelling by bus was having a "free" bus pass as trains were considered too expensive for everyday use although some would use them for long journeys if they could book in advance to get a cheaper deal.

Well I never travelled on a bus for I think decades practically till I got my bus pass. It's quite an adventure going (Male 66 years car).

\subsection{Access to travel and interaction with the transport}

Access to the buses was considered to be good with most people having a bus stop within easy walking distance and the lower bus floors meant they could walk on with a walker if the kerbs had been raised appropriately. However once on the bus there were other obstacles to navigate round and this was difficult with a walker.

Well they forget, they're thinking about the old buses where you just walked up and sat down wherever you wanted to. Now there's, halfway up there's a step and then there's another high step. And the steps are high. Yes, yes, I've helped them. (Female 67 years bus user).

Pushchairs were an issue for the older bus users as they took up space near the front of the bus and blocked the aisle making it difficult to negotiate a path to the seats and for one created an injurious incident.

there's always a lot of prams, yeah (Female 63 years bus).

... it's two or three prams go on the bus, if you go on the bus ...that's what stopped me going on the bus. I bet I've not been on the bus for nearly 12 months. (Female 89 car-reliant on others).

\subsubsection{Seating}

Where someone sat was a conscious choice and was dependent on a number of factors whether they were carrying shopping and also the seats available when they got on. Preference was shown for the forward-facing seats at the front of the bus and sitting down as soon as possible.

If I could, [sit near the front] yeah. There are too many steps near the back! (Female 81 years bus).

I prefer near the forward [or the] middle [but rear] is too swaying (Male 76 years bus). 
The flip down sides seats were only a choice when they had heavy shopping or a shopping trolley or a walker even though some felt unsafe and thrown around and had nothing to hold onto.

If I had heavy shopping sometimes, if there's nowhere [else to sit] (Female 73 years bus).

They're not very safe to sit in the flip ups...If they jolted they would go forward wouldn't you? You've got nothing to hold, there's nothing to hold on ...(Female 63 years bus-walk).

Going upstairs on the bus for a seat was only a viable option for two of the males who liked the view, everyone else always sat downstairs or if there wasn't a free seat would 'take their chances' standing than risk being thrown whilst traversing the stairs.

\subsection{Alighting and boarding}

Alighting buses identified mixed behaviours with five of the participants stating they rang the bell and always waited for the bus to stop before they got up. For the others their choice was dependent on factors such as where they were sat, whether they had shopping bags, previous experiences or was a matter of routine for them.

I usually get up prior to him stopping, yeah (and hold onto) the vertical upright, the vertical pillars. No I take my chances (Male 69 years bus).

I get up before, to make sure I get off! You know in time.... I wait for it to stop if I've got shopping. I get up, but if it's me and my bags, that's it, I'll sit there till it stops (Female 69 years bus).

Boarding the bus was seen as problematic for a few people and they had observed that bus drivers didn't wait for people to sit down before moving off from the stop.

They pull off before you're sitting down and that ..(I don't ask them to wait) No, I might get a rude answer (Female 76years bus user).

However, others reported that the driver always waited for them to sit down and possibly may be because of the frequency they travelled the route and also they used a walking aid which might make the driver more aware of their needs.

\subsubsection{Incidents}

There were two incidents experienced by the participants that involved stumbles and falls on the bus.

I was trying to negotiate my way down to the rear of the bus because that's where the vacancies were (lady speaking in background) ... And all of a sudden he's veered and I just fell on the floor, just lost my balance, fell on the floor, hurt my leg...I was sore for a couple of days afterwards (Male 69 years Bus).

I went on the bus but I had a problem when I caught my leg on the perambulator ... And I thought, oh well I can't go on again (Female 89 years reliant). 
The former incident wasn't reported to the bus driver also the person felt that the bus driver was not even aware that the incident had happened. The experience didn't put him off travelling on the bus it's a question of you either use the bus or you don't use the bus. In contrast to this a female participant had not been back on a bus since lacerating her leg on a pushchair in the aisle.

\subsection{Stakeholder and bus driver perspectives}

Specific responses are presented related to the views and opinions on accident / injuries involving older public transport users. The main type of accidents identified by the stakeholders related to having 'falls or tripping' when getting on the bus, walking to their seat, falling off seats and getting up too soon before the bus stops. It was considered by 7 respondents that these accidents differed to those involving younger passengers, although there was also a perception that they did not differ only the outcomes were more serious.

Need caution here. Accidents will be similar - i.e. falling over - but impacts of that fall higher with age (User group)

Older people tend to fall over completely whereas younger people tend to maintain their balance (PTEG).

The stakeholders identified a number of design factors they considered to contribute to the cause of older passengers being injured in accidents which were also raised by the older passengers, for example

- Distance to walk to priority seating because the wheelchair access is at the front of the bus

- Location of stanchions resulting in long distances without something to hold on to

- Seat pitches

- Driver attitude and behaviour - acceleration, deceleration, waiting for people to take seats

- People no longer give up seats for elderly people who then have to stand.

- Elderly people often feel concern at missing their stop or taking too long to get off the bus so they stand up well in advance of the bus reaching the stop

Bus drivers mostly $68 \%(\mathrm{n}=19)$ would always wait for older people to sit down as they recognised this was a problem, however there were some circumstances where a driver would not wait for an older user to sit down and these included whether the driver could see down the bus, they were taking too long and would affect the timetabling and if they chose to stand to chat to friends. Drivers often found it difficult to be aware whether a person had fallen on the bus with 11 drivers stating they would be aware and 11 stating the opposite. The main reason given for not being aware of falls was the passenger doesn't always report it and the difficulty of seeing down a loaded bus.

Only 4 drivers had experience of an older person being injured on their bus whilst driving but only 2 passengers had an incident form completed by the driver. However stumbling occurred more frequently than actual falls in older passengers $(n=15)$ again just under a half had an incident form completed $(n=6)$. Seven drivers didn't complete a form and 2 stated they didn't have to report the incident. 


\section{DISCUSSION}

Overall bus passes mean more to the older bus users than a free method of travel they provide freedom, route to social interactions, leisure opportunities, as well as the essential daily needs of shopping and banking. There was however specific behaviours and challenges to be negotiated by the older bus users to ensure they felt safe and confident. If reviewed in the context of potential injurious situations, ultimately the older passengers want to sit near the front of the bus, be able to sit down before the bus drives off from the stop, have something to hold onto and be offered a seat on a full bus and wait until the bus stops before standing to alight without fear of missing their stop. In reality many older passengers stand up too soon and risk falling to ensure the driver knows they want to alight, furthermore side seats were considered to be unsafe and they would walk further to sit down which meant negotiating obstacles such as pushchairs in conjunction with this the bus might drive off. All these issues were recognised by the stakeholders and as a passenger group were considered potentially more at risk of injuries than younger passengers. Some of these challenges could be addressed through design of the internal layout of the buses [5], however some are more ingrained in the behaviour of older passengers and drivers.

Although these challenges are recognised it is apparent there is no cohesive approach to solving these issues. Having a national injury data surveillance system to capture incidents on buses would be a useful resource to the stakeholder organisations for comparative assessments of safety and incidents on buses that could promote new design features, safety practices, passenger education and driver training and guidance.

\section{ACKNOWLEDGEMENT}

This research is funded by the MRC Lifelong Health and Wellbeing programme (LLHW), Grant Number G1001863/1. LLHW is a cross council initiative in partnership with the UK health departments and led by the MRC.

\section{REFERENCES}

[1] Lucas, K., Tyler, S. \& Christodoulou, G., The value of new public transport in deprived areas: Who benefits, how and why? Joseph Rowntree Foundation, New York, (2008).

[2] Barnes, J., Morris, A.P., Welsh, R., Summerskill, S., Marshall R., Kendrick, D., Logan, P., Drummond, A., Conroy, S., Fildes, B. \& Bell, J., Injuries to older users of buses in the UK. Public Transport, 8(1), pp 25-38, 2016.

[3] Barnes, J., Lawton, C., Morris, A., Marshall, R., Summerskill, S., Kendrick, D., Logan, P., Drummond, A., Fildes, B. \& Conroy, S., Improving safety for older public transport users (OPTU) - a feasibility study. Loughborough University, 2013.

[4] Green, J. \& Thorogood, N. (eds) Qualitative Methods for Health Research. Sage Publishing. London, 2014.

[5] Marshall, R., Summerskill, S., Case, K., Hussain, A., Gyi, D., Sims, R., Morris, A. \& Barnes, J., Supporting a Design Driven Approach to Social Inclusion and Accessibility in Transport. Social Inclusion, 4(3), pp. 7-23, 2016. DOI:http://dx.doi.org/10.17645/ si.v4i3.521 